\title{
Information Processing Theory in Budgetary Participation: Its Antecedent and Consequence
}

\author{
Dian Indri Purnamasari ${ }^{1}$ and Rahmawati ${ }^{2}$ \\ ${ }^{1}$ Pembangunan Nasional University "Veteran" Yogyakarta-Indonesia \\ ${ }^{2}$ Sebelas Maret University Solo-Indonesia \\ E-mail: ${ }^{1}$ indri_mtc@yahoo.com, ${ }^{2}$ rahmaw2005@yahoo.com
}

\begin{abstract}
This study analyzes the role of the Information Processing Theory (IPT) in the budgetary participation with antecedent variables such as environmental dynamism (ED). Furthermore this study examines the influence of budgetary participation on performance (P) in the company. The IPT is used in this study as a contribution to overcome the gap between dynamic environments, information management, budgetary participation and performance. This research concluded that (1) there is a positive relationship between environmental dynamism and task exceptions, information technology, information systems, and budgetary participation, (2) there is no negative relationship between environmental dynamism and task analyzability , (3) there is no positive relationship between task exceptions and budgetary participation, (4) there is a negative relationship between task analyzability and budgetary participation, (5) there is a positive relationship between information technology, and information systems for budgetary participation, and (6) there is a positive relationship between budgetary participation and performance.
\end{abstract}

Keywords: Process, Information, Participation, Budget, Performance.

\section{INTRODUCTION}

Companies today are confronted with dynamic and competitive business environments; therefore they will have to improve their sensitivity to and readiness for any environmental changes. External conditions such as dynamic environments, or turbulent environments in some senses, require the availability of multiple sources of information to cope with them and to survive in the competition [1]. The study aims to analyze how the companies respond to dynamic business environments by applying Information Processing Theory (IPT) in budgetary participation.

IPT is concerned with how information is developed in a structured way to facilitate the users in utilizing information for the purpose of decision making [2]. Information plays an important role as input and process in decision making related to the generated decisions, as is the case in budgetary participation. Questions then arise as to how IPT applies in a corporate environment: Has IPT been able to influence the dynamic environments to generate relevant information? Has IPT been able to connect to and to facilitate the budgetary participation and did it ultimately result in increased performance efficiency?

Gattiker [3] concluded in his study that information processing is necessary to serve the purposes of, among other, minimizing inefficiency and/or slack in budgeting. It is required to reduce the gap between information needs and information capacity, and to minimize creating slack from the use of organizationnal resources [3]. The arising question from these considerations would be how information technology can be applied in organizations. Has the information been supported by adequate technology? The aforementioned questions are worth to be further investigated in a study. This research analyzes the role of IPT in budgetary participation with the antecedent variable of environmental dynamism (ED) and the consequence variable, of performance $(\mathrm{P})$ in companies.

Based on this description, the authors formulated the research questions as follows: (1) does environmental dynamism correlate to task exceptions, 
task analyzability, information technology, information system, and budgetary participation? (2) Do relationships exist between task exceptions, task analyzability, information technology, information systems and budgetary participation? (3) Does a relationship exist between budgetary participation and performance?

\section{HYPOTHESIS DEVELOPMENT}

\subsection{Environmental Dynamism and Information Processing Theory}

According to Kren [4], environmental Dynamism (ED) refers to volatility, which means the changes occurre naturally, cannot be anticipated easily and the manager is only able to predict the impact of certain environmental factors and their relationship with uncertainity. In budgeting, volatility is expected to correlate positively to the level of budgetary participation [4]. Simon [5] supposed that when volatility increases, various information processing would not be useful in decision-making if made by lower hierarchical levels of the organization. Hopwood [6] and Govindarajan [7] revealed that the budgetary participation will increase in highly volatile organizations, due to the demands to respond immediately to the already established budget whenever changes in a dynamic environment occur. A dynamic and complex environment plays a significant role in information processing [8].

Chong and Johnson [9] used uncertainty as a variable of information system theory and divided it into two dimensions; Task Exceptions (TE) and Task Analyzability (TA). TE is defined as the frequency of unexpected occurrence in a conversion process [10]. But if TE is recognized early enough, efforts can be made to prevent TE. When TE is low, the tasks can be accomplished on routinely and repetitive basis using the procedures and regulation available thus far [11], when the TE is high, it is likely that the staff will face serious problems [12]. TA is defined as the extent to which some of the activities or works can be reduced to technically programmatic measures [10]. A dynamic environment is characterized by information overload, information diversity, and a high rate of information change [8] and will increase TE. On the other hand, a dynamic environment is negatively related to the TA because TEs are unpredictable and cannot be simplified.

A dynamic environment must be balanced with IT availability supporting information acquisition as a consequence of information dynamics. Sufficient IT availability will maximize the acquisition of the necessary information for decision-making $[13,14]$ and will sort information in such a way that the user will find it easier to understand and improve the efficiency of knowledge processing in decision-making [15].

Gattiker [3] noted in his study "Enterprise Resources Planning (ERP) System of marketing" that one variable in IPT is an information system to be managed properly to anticipate environmental changes. Edmonds [8] inferred that a linear relationship exists between information processing and environmental complexity; the more complex the environmental change is, the higher the needs of information processing will be.

A dynamic environment requires the manager to participate in information acquisition and in anticipation of unexpected occurences [16]. Shields and Shields [17] drew the conclusion in their study that dynamic environments are the antecedents of budgetary participation. Wing et al. [18] found a relationship between a dynamic environment and budgetary participation.

Based on the aforementioned description, the authors present the following hypotheses:

H1a: Environmental dynamism is positively influence task exceptions, information technology, information system, and budgetary participation.

$\mathrm{H} 1 \mathrm{~b}$ : Task analyzability is negatively influence to environmental dynamism and task analyzability.

\subsection{Information Processing Theory and Budgetary Participation}

Task uncertainty including TE and TA is the antecedent of the budgetary participation [9]. Lower TA takes employees a longer time to think and to find solutions outside of the existing procedures and policies and requires a lot of information, which in turn requires a higher level of participation. Higher TE makes it difficult for subordinates to predict the problem they are facing, and it is expected that there is a high budgetary participation to minimize the difficulty in predicting [19, 12, 9].

The presence of information technology, which is necessary in the information processing, reduces inefficiencies and gaps in many such things as budgetary participation [3]. Information technology can improve the information absorbed [15] and the efficiency of budgetary participation. Organizations with strategic information processing will process their information in an integrated activity involving individuals and the organization [20]. Venkatraman [21] summarized that IS passes knowledge to the users, who then will influence the actions of organizations in making business decisions, such as budgetary participation. 
Based on the above description, the authors present the following hypotheses:

H2a: Task exceptions, information technology, information system are positively influence budgetary participation.

$\mathrm{H} 2 \mathrm{~b}$ : Task analyzability is negatively influence budgetary participation.

\subsection{Budgetary Participation and Performance}

In general, the relationship between budgetary participation and performance is positive, which was also the result of the following studies: Penno [22] stated that budgetary participation by employees will be positively correlated to their performance. For his research, he used a principalagent model. Kren [4] concluded that participation affects performance indirectly. Further analysis yielded that positive performance is the result of participation and would be perceived more as such in a highly volatile environment.

Greenberg et al. [23] concluded in his metaanalysis that there is a positive relationship between budgetary participation and performance. Wing et al. [18] came to a similar conclusion like Greenberg. Lopez et al. [24] tested a path model and concluded that there is a strong relationship between budgetary participation and performance among U.S. managers working in the U.S. and Mexican manager working in the U.S.

Based on the above description, the author presents the following hypothesis:

H3: Budgetary Participation is positively influence Performance.

\section{RESEARCH METHOD}

\subsection{Populations and Sampling}

The population in this study consists of managers of companies in Yogyakarta and Surakarta. The sampling was performed using nonprobability sampling technique, i.e. purposive sampling. The requirement was a minimum of two years of working experience and that the manager has created a budget for their respective division in each fiscal year.

\subsection{Variable Measurement}

Environmental dynamism is the uncertainty of fluctuating changes from various conditions both inside and outside an organization. It is measured with an instrument developed by [25] that consists of 12 items, each using a five point Likert scale. Task exception, which is the frequency of unexpected occurrence in a conversion process [10] as already mentioned, is measured using a five item questionnaire developed by [12]. Task analyzability, which was defined as the extent to which some of the activities or works can be reduced to programmable technical measures [10] is measured with a four item questionnaire developed by [12]. Information technology, the availability of facility and infrastructure for data processing, is measured using a three item questionnaire adopted and developed by [15]. The variable Information System describes how the existing system in an enterprise has been established up to the present and should be maintained established in the future. This variable is measured using a ten item questionnaire adopted and developed in the study of Osborne [26]. Budgetary participation describes the involvement of subordinates by allowing them to organize their tasks according to like they think it best. It is measured using an instrument developed by [27], a questionnaire consisting of six questions. Performance of management, consisting of the achieving of goals, the completing of tasks and a good overall behavior, is measured by a nine item questionnaire developed by [28].

\section{DATA ANALYSIS AND DISCUSSION}

\subsection{Data Collection}

Table 1:Data Collection

\begin{tabular}{|l|c|}
\hline \multicolumn{1}{|c|}{ Questionnaire Information } & Total \\
\hline Distributed questionnaires & 600 \\
\hline Returned questionnaires & 600 \\
\hline Unusable questionnaires & 56 \\
\hline Total questionnaires used & 544 \\
\hline Return rate of response & $100 \%$ \\
\hline Rate of used questionnaires & $90 \%$ \\
\hline
\end{tabular}

Source: Data are processed

The authors distributed questionnaires to 600 respondents, but 56 of them couldn't be used in subsequent analyses for various reasons and considerations, for example because the respondents are managers who do not meet the eligibility criteria or the returned questionnaire was incomplete.

\subsection{Full SEM (Structural Equation Model Analysis) Model}

The validity testing indicated that some instruments have a factor loading of $<0.4$, and are thus removed from the analysis. Because of this reason, five items of ED, three items of IS, three items of budgetary participation and one item of the 
performance variable were eliminated. The reliability testing was performed using construct Reliability (CR) to indicate the extent to which an instrument gives a relatively similar result when measured again for the same object. This is the case when the $C R$ value exceeds 0.7 , but a $C R$ value between 0.6 and 0.7 is also acceptable if the indicators of the model were good, because they fulfilled the criterions of the SEM Assumptions [29]. The results of reliability testing for all variables are valid.

\subsection{Testing of SEM Assumptions}

Evaluation of normality is performed using the criterion of critical ratio for a skewness value of \pm 2.58 at the level of significance of 0.01 [29]. The test results indicated that the critical ratio for the skewness value for all indicators was normally distributed as it is less than 2.58. Outlier testing at a significance level of $\mathrm{p}<0.0001$ resulted in a value of 85.35, which means that all the cases were considered not as outliers if the Mahalnobis distance value is below 85.35. The test results showed that none of these cases has a Mahalnobis distance value which is higher than 85.35 and therefore it can be concluded that there are no outliers in the data. The test for multicollinearity of the determinant of sample covariance matrix indicated the value of 6.290. As that number is far from zero, it can be concluded that there is no multicollinearity problem and the data can be analyzed.

\subsection{Feasibility Testing of Research Model}

The research employed an absolute measure of fit for the purpose of evaluating overall model fit, for structural model and measurement model simultaneously [29]. Indicators to be met in an absolute measure of fit are:

Table 2: Construct Goodness of Fit

\begin{tabular}{|l|c|c|c|}
\hline \multicolumn{1}{|c|}{ Criteria } & $\begin{array}{c}\text { Ctical } \\
\text { Value *) }\end{array}$ & Result & Conclusion \\
\hline Chi-square & Small & 905 & Marginal \\
\hline Probability & $\geq 0,05$ & 0,000 & Marginal \\
\hline CMIN/DF & $\leq 2,00$ & 1,640 & Good \\
\hline GFI & $\geq 0,90$ & 0,762 & Marginal \\
\hline RMSEA & $\leq 0,08$ & 0,620 & Good \\
\hline
\end{tabular}

Source: *) Hair et al. [30], Arbuckle [31], and data are processed

The table above indicated that there are two indicators eligible for concluding that the model is fit; CMIN/DF and RMSEA. The Chi-square test known to be very sensitive to large sample sizes is advisable to be ignored, and instead it is advised to rely on other goodness of fit tests [32, 29]. Byrne [32] suggested if there exist one or two goodness of fit criteria that have been met; the model can be considered as well-fitting.

\subsection{Hypothesis Testing}

The next step is hypothesis testing by output of regression weight as follows:

Table 3: Construct Goodness of Fit

\begin{tabular}{|c|c|c|}
\hline Relationship & Estimate & p \\
\hline $\begin{array}{l}\text { Environmental Dynamism } \\
\rightarrow \text { Task Exception }\end{array}$ & .016 & $.000 *$ \\
\hline $\begin{array}{l}\text { Environmental Dynamism } \\
\rightarrow \text { Task Analyzability }\end{array}$ & .584 & $.003 *$ \\
\hline $\begin{array}{l}\text { Environmental Dynamism } \\
\rightarrow \text { Information Technology }\end{array}$ & .345 & $.005^{*}$ \\
\hline $\begin{array}{l}\text { Environmental Dynamism } \\
\rightarrow \text { Information System }\end{array}$ & .550 & $.003 *$ \\
\hline $\begin{array}{l}\text { Environmental Dynamism } \\
\rightarrow \text { Budgetary Participation }\end{array}$ & .481 & $.007 *$ \\
\hline $\begin{array}{l}\text { Task Exception } \rightarrow \\
\text { Budgetary Participation }\end{array}$ & -.360 & $.000 *$ \\
\hline $\begin{array}{l}\text { Task Analyzability } \rightarrow \\
\text { Budgetary Participation }\end{array}$ & -.209 & $.004 *$ \\
\hline $\begin{array}{l}\text { Information Technology } \rightarrow \\
\text { Budgetary Participation }\end{array}$ & .117 & $.019 *$ \\
\hline $\begin{array}{l}\text { Information System } \rightarrow \\
\text { Budgetary Participation }\end{array}$ & .132 & $.023 *$ \\
\hline $\begin{array}{l}\text { Budgetary Participation } \rightarrow \\
\text { Performance }\end{array}$ & .354 & $.000^{*}$ \\
\hline
\end{tabular}

Hypothesis 1a stated that a dynamic environment is positively related to task exceptions, information technology, information systems, and budgetary participation. Based on the results of the hypothesis testing, a positive and significant standardized coefficient value is obtained, and thus it can be concluded that hypothesis $1 \mathrm{a}$ is statistically supported. Hypothesis $1 \mathrm{~b}$ predicted a negative relationship between dynamic environment and task analyzability. From the hypothesis testing, a standardized coefficient of 0.584 and a $p$ value of 0.003 were obtained. This gives evidence that a dynamic environment is positively related to task analyzability; therefore hypothesis $1 \mathrm{~b}$ cannot be supported.

The results of the analysis are in accordance with those of previous studies, as described as follows: they confirm that dynamic environment plays an important role in information processing [8]. The higher the dynamic level of an environment, the 
more positive is its relationship with TE. This means that there will arise many more unanticipated events or activities as a result of an uncertain surrounding environment. The results of the analysis are also in line with the findings of Tushman and Nadler [11] and Bystrom [33]. A dynamic environment will generate sufficient needs for IT, or, to put it another way, the higher the dynamic level of an environment, the more positive is its relationship with IT as a mean of information processing resulted from the dynamic environment. The findings agree with those of studies conducted by Galbraith [34, 35], Hubber [13], Kendall [14] and Song et al. [25], who stated that dynamic environments require IT as tool to process information more optimally in decision making.

Dynamic environment turned out to be positively associated with the needs for the IS, which means that a maximum IS support will be able to cope with and anticipate changes in the dynamic environment, and this is in accordance with the results of the research by Lodr and Maher [36] and [8]. Kren [4] used the term volatility to indicate that dynamic environments are positively related to budgetary participation; an increasingly dynamic environment will have increasingly needs for budgetary participation. The analysis also confirmed that an environment that is dynamic in nature did increase the budgetary participation.

The analysis indicated that $\mathrm{H} 1 \mathrm{~b}$ is not supported in this study. In theory, a dynamic environment lowers the TA, which is logical since the dynamic in an environment makes it impossible to analyze the various tasks on a simplistic and programmatic basis. How is it possible to make something very dynamic into a simple and programmed thing, as if homogeneity and stagnancy are frequent to occur? The results tell us that a positive relationship existed between the dynamic environment and TA, which is most likely because the respondents expect that the dynamic environment can be simplified to make it easier to obtain information and to make decisions. The respondents realized that their environment is dynamic but they hoped that the complexity of activities and processes in that dynamic environment can be simplified to facilitate the decision-making.

Hypothesis 2a stated that task exception is positively associated with information technology, information system, and budgetary participation. Based on the hypothesis testing, an estimated standardized coefficient that is positive and significant was obtained and made the authors think in the first instance hypothesis 2 would be supported. But then the authors found out that the coefficients of the relationship with task exception are still significantly negative, and thus the hypothesis cannot be supported statistically. Hypothesis $2 \mathrm{~b}$ claimed that a positive relationship exists between task analyzability and budgetary participation. With the hypothesis testing, estimated standardized coefficients of -0.029 and $p=0.004$ were obtained, thus indicating that there is a negative relationship between task analyzability and budgetary participation, therefore the hypothesis $2 \mathrm{~b}$ cannot be supported.

TA is negatively correlated to budgetary participation since the activities in a TA that can easily be simplified and programmed are often abound and thereby it is not urgent to deal with budgetary participation. The higher the TA, the lower the budgetary participation will be. This is in accord with the study by [9]. Meanwhile, IT and IS are positively correlated with budgetary participation, because sufficient availability of IT will help subordinates and managers to deal with necessary information and increase the budgetary participation. If IS is part of a plan it is also positively related to budgetary participation. This indicated that the maximum planning of a budget of an IS will support budgetary participation and facilitate decision-making.

The analysis indicated that TE is negatively related to budgetary participation. This means that the more unexpected events occur in the daily business, the lower the budgetary participation will be, because in such a case the respondents feel no necessity for budgetary participation, because they assume the activities of budgetary participation will be unpredictable. Managers feel that when TE is high, budgetary participation is not necessary to consider because it will lead to a suboptimal decision making which will not comply with the budgeting and always change.

Hypothesis 3 stated that budgetary participation is positively correlated to performance. From the hypothesis testing, an estimated standardized coefficient of 0.354 and $p=0.00$ was obtained, and thus indicates that budgetary participation and performance are indeed positively related, and hypothesis 3 is supported. Budgetary participation results in more optimal performance. This is due to the fact that budgetary participation lets us know more activities and how to evaluate them.

\section{CONCLUSION AND SUGGESTION}

The study concluded that (1) environmental dynamism is positively correlated to task exceptions, information technology, information system, and budgetary participation, (2) There is no negateve relationship between environmental dynamism 
and task analyzability, (3) a positive relationship between task exceptions and budgetary participation does not exist, (4) a negative relationship exists between task analyzability and budgetary participation, (5) information technology and information system are positively correlated to budgetary participa-tion, and that (6) there is a positive relation between budgetary participation and performance. Future research may compare budgetary participation among various business sectors, such as state owned enterprises and private owned enterprises or banking and non-banking financial institutions.

\section{REFERENCES}

[1] Mulyadi, 2005, Sistem manajemen Strategik Berbasis Balanced Scorecard, Yogyakarta: UPP AMP YKPN.

[2] McGuire, 2011, McGuire's Information Processing Model in Persuasive Communication, http://www.clas.ufl.edu/users/kenwald/pos323 3/mcguide.htm.

[3] Gattiker, T. F., 2007, Enterprise Resources Planning (ERP) Systems and the Manufacturing-Marketing Interface: An Information-Processing Theory View, International Journal of Production Research, Vol. 45., No. 13, 1 July.

[4] Kren, Leslie, 1992, Budgetary Participation and Managerial Performance: The Impact of Information and Environment Volatility, The Accounting Review, Vol. 67, No. 3, July.

[5] Simons, R., 1987, Planning, Control, and Uncertainty: A Process View, Accounting and Management: Field Study Perspective, Cambridge.

[6] Hopwood, A., 1976, Accounting and Human Behavior, England Cliffs, NJ, Prentice Hall.

[7] Govindarajan, V., 1986. Impact of Participation in The Budgetary Process on Managerial Attitudes and Performance: Universalistic and Contingency Perspective, Decision Sciences. Vol 17, p. 496-516.

[8] Edmonds, Thomas, P., 2001, The Effect of Environmental Complexity on the Level of Information Processing by Introductory Accounting Students, Issues in Accounting Education.

[9] Chong, V. and Johnson, D.., 2007, Testing a Model of The Antecedents and Consequences of Budgetary Participation on Job Performance, Accounting and Business Research, Vol. 37, No. 1.
[10]Brownell, P and Dunk, A.S., 1991, Task Uncertainty and Its Interaction with Budgetary Participation and Budget Emphasis: Some Methodological Issues and Empirical Investigation, Accounting, Organizations and Society, Vol. 16, No. 8.

[11]Tushman, M.L. and Nadler, D.A., 1978, Information Processing as An Integrating Concept in Organizational Design, Academy of Management Review.

[12] Withey, M., Daft, R.L. and Cooper, W.H., 1983, Measures of Perrow's Work-Unit Technology: An Empirical Assessment and A New Scale, Academy of Management Journal, Vol 26, no. 1.

[13] Huber, G.P., 1990, A Theory of the Effects of Advanced Information Technologies on Organizational Design, Intelligence, and Decision Making, Academy of Management Review, 15 (1).

[14]Kendall, K.E., 1997, The Significance of Information Systems Research on Emerging Technologies: Seven Information Technologies that Promise to Improve Managerial Effectiveness, Decision Sciences, 28 (4).

[15] Song, Michael, Hans van der Bij, and Mathieu Weggeman, 2005, Determinants of the Level of Knowledge Application: A KnowledgeBased and Information-Processing Perspective, J Product Innovation Management, 22.

[16] Brownell, P and Hirst, M. 1986. "Reliance on Accounting Information, Budgetary Participation, and Task Uncertainty:TestS of a Three-way interaction", Journal of accounting Research. Vol. 24.

[17] Shields, J.F. and Shields, M.D., 1998, Antecedents of Budgetary Participation, Accounting, Organizations and Society, Vol 23, No. 1.

[18] Wing, B.W., Guo, L. and Lui, G., 2010, Intrinsic and Extrinsic Motivation and Participation in Budgeting: Antecedents and Consequences, Behavioral Research in Accounting, Vol. 22, No. 2.

[19]Perrow, C., 1967, A Framework for Comparative Organizational Analysis, American Sociology Review, 32.

[20] Corner, P. D., Kinicki, A. J., \& Keats, B. W, 1994, Integrating organizational and individual information processing perspectives on choice, Organization Science, 5.

[21] Venkatraman, N, 1996, The Value Centre, presentation made at Cranfiels School of Management.

[22]Penno, Mark, 1990, Accounting Systems, Participation in Budgeting, and Performance 
D. I. Purnamasari and Rahmawati / International Journal of Computer Networks and Communications Security, 2 (1), January 2014

Evaluation, The Accounting Review, Vol. 65, No. 2.

[23] Greenberg, P., Greenberg, R. and Nouri, H., 1994, Participative Budgeting: A MetaAnalytic Examination of Methodological Moderators, Journal of Accounting Literature, Vol. 13.

[24]Lopez, M. A. L., William, W. S., and Frances, M. N., 2007, Differences in the Role of JobRelevant Information in the Budget Participation-Performance Relationship among U.S. and Mexican Managers: A Question of Culture or Communication, Journal of Managemnt Accounting Research, Vol. 19, No.1.

[25]Duncan, R. B., 1972, Multiple DecisionMaking Structures in Adapting to Environment Uncertainty: The Impact on Organizational Effectiveness, Human Relations, Vol 26, No. 3.

[26] Osborne, T., 1994, Current Portfolio Questionnaire, Working Paper, Glaxo Wellcome Operations.

[27] Milani, K., 1975, Budget-Setting, Performance and Attitudes, The Accounting Review, 50, April.

[28] Mahoney, T. A., T. H. Jerdee, and S. J. Carroll, 1965, The Job(s) of Management, Industrial Relations, Vol. 4, No. 3, February.

[29] Ghozali, Imam, 2005, Model Persamaan Struktural: Konsep dan Aplikasi dengan Program AMOS Ver. 5.0, Diponegoro University Publisher.

[30] Hair, Joseph, Rolph Anderson, Ronald Tatham and William Black, 1998, Multivariate Data Analysis,5th edition, Prentice Hall International Inc, New Jersey.

[31] Arbuckle, J.L., 1997, Amos User's Guide version 3.6, Small Waters Corporation.

[32]Byrne, B. M., 2010, Structural Equation Modelling with AMOS: Basic Concepts, Applications, and Programming, 2nd ed, Taylor and Francir Group, NY 10016.

[33] Byström, K., 1999, Information seekers in context: an analysis of the 'doer' in INSU studies. In (eds.) Wilson, T.D. \& Allen, D.K. Exploring the Contexts of Information Behaviour. Taylor Graham: London, UK.

[34] Galbraith J., 1973, Designing Complex Organization, Reading, MA: Addison-Wesley.

[35] Galbraith J., 1977, Organizational Design, Reading, MA: Addison-Wesley.

[36] Lord R. G, and Maher K. J., 1990, Alternative information-processing modelsand their implications for theory, research, and practice. Academy of Management Review, 15, No.1. 